female, but in male patients these clinical clues could have some diagnostic value.

But ultimate diagnosis must depend on full investigation with electromyography, serum enzyme studies, and muscle biopsy. The distinction is important, because Duchenne muscular dystrophy is invariably a progressive and fatal disorder. In some patients with spinal muscular atrophy the disease may undergo temporary or even prolonged arrest, and often the prognosis is better than it is in cases of the Duchenne type. Furthermore, an accurate diagnosis is needed for genetic counselling, as the sisters of boys suffering from Duchenne dystrophy may possibly be carriers of the $\mathrm{X}$ linked gene, whereas unaffected sibs of a child with spinal muscular atrophy of autosomal recessive inheritance are unlikely to pass on the disease to their offspring unless they marry a blood relation.

1 Kugelberg, E., and Welander, L., Archives of Neurology and Psychiatry, $1956,75,500$.

2 Dubowitz, V., Brain, 1964, 87, 707

Gardner-Medwin, D., Hudgson, P., and Walton, J. N., fournal of the Neurological Sciences, $1967,5,121$.

4 Munsat, T. L., Woods, R., Fowler, W., and Pearson, C. M., Brain, 1969, 92, 9.

5 Fried, K., and Emery, A. E. H., Clinical Genetics, 1971, 2, 203.

6 World Federation of Neurology, Research Group on Neuromuscular Diseases, Fournal of the Neurological Sciences, 1973,18,493.

- Mastaglia, F. L., and Walton, J. N., Fournal of the Neurological Sciences, $1971,12,15$.

${ }^{8}$ Drachman, D. B., Murphy, S. R., Nigam, M. P., and Hills, J. R., Archives of Neurology, 1967, 16, 14 .

${ }^{9}$ Moosa, A., and Dubowitz, V., Archives of Disease in Childhood, 1973, 48 , 386.

${ }^{10}$ Brandt, S., Werdnig-Hoffmann's Infantile Progressive Muscular Atrophy.

Copenhagen, Munksgaard, 1950.
11 Byers, R. K., and Banker, B. Q., Archives of Neurology, 1961, 5, 140.

12 Spiro, A. J., Fogelson, M. H., and Goldberg, A. C., Developmental Medicine and Child Nourology, 1967, 9, 594.

13 Peters, H. A., Opitz, J. M., Goto, I., and Reese, H., Acta Neurologica Scandinavica, 1968, 44, 542.

\section{Does Crohn's Disease Predispose to Intestinal Cancer?}

It is a well-documented fact that long-standing ulcerative colitis predisposes to the development of carcinoma of the large intestine. ${ }^{1}$ This risk has to be taken into account when considering the practical management of patients suffering from colitis.

It is natural to ask whether the other common inflammatory condition of the intestinal tract, Crohn's disease, carries a similar potential for producing malignant tumours of the bowel. In a way it might be surprising if it did, for unlike ulcerative colitis, in which the inflammatory process is located predominantly in the mucosa, in Crohn's disease the maximal changes occur in the submucosa and deeper layers, though it is rare for the mucous membrane entirely to escape. But what counts is what actually happens in practice. There have been several attempts ${ }^{2-5}$ to assess the frequency of intestinal carcinoma in Crohn's disease and determine whether the two conditions are causally related or not. Most of these studies have reached rather equivocal conclusions, but recently S. G. Darke and his colleagues ${ }^{6}$ at the London Hospital have thrown fresh light on this debatable question.

Dealing first with carcinomas of the small bowel associated with Crohn's disease, Darke and his colleagues found that the average age at the time of diagnosis in 25 published cases was 46 years but that in a group of cases of small bowel carcinoma unassociated with Crohn's disease it was 61,7 a statistically significant difference. The distribution of the "Crohn's carcinomas" was different from that of spontaneously occurring carcinomas of the small bowel; the former occurred mainly in the lower ileum, the latter were more evenly located throughout the small intestine. ${ }^{8}$ The incidence of spontaneously occurring carcinoma of the small bowel has been estimated at 0.3 per 100,000 population per year. ${ }^{10}$ The prevalence of Crohn's disease at all sites in the intestinal tract has been put at 9 per 100,000.11 The chances of the two conditions occurring together is thus no more than 1 in a thousand million. But in several large series of published cases of Crohn's disease of the small bowel the incidence of carcinoma averaged $0.3 \%$.

As to "Crohn's carcinomas" of the large bowel, Darke and his colleagues found that there was no significant difference between the average age at diagnosis of these growths and that of spontaneously occurring colo-rectal carcinomas. ${ }^{12}$ However, the distribution of these two forms of growth was dissimilar in that the Crohn's carcinomas were commoner in the proximal colon, the ordinary colo-rectal cancers in the distal colon and rectum. ${ }^{13}$ As regards overall incidence, Darke and colleagues calculated from several sources ${ }^{14} 15$ that the incidence of spontaneously occurring carcinoma of the large bowel is roughly 60 per 100,000 population. The prevalence of Crohn's disease of the colon and rectum is probably about 6 per $100,000.11$ The chances of a coincidental association of carcinoma and Crohn's disease of the large intestine is thus about 1 in 10 million. But the actual incidence of carcinoma in the colon and rectum associated with Crohn's disease averages $1.8 \%$ in published series. ${ }^{6}$

As a consequence of these observations Darke and his colleagues ${ }^{6}$ consider that there is a small but significant risk of carcinoma developing, both in the small and in the large intestine, in Crohn's disease.

${ }^{1}$ Goligher, J. C., de Dombal, F. T., Watts, J. M., and Watkinson, G. Ulcerative Colitis. London, Baillere, Tindall and Cassel, 1968.

2 Shiel, F. O'M., Clarke, C. G., and Goligher, J. C., British fournal of Surgery, 1968, 55, 53 .

3 Perrett, A. D., Truelove, S. C., and Massarella, G. R., British Medical Fournal, 1968, 2, 466 .

4 Jones, J. H., Gut, 1969, 10, 651.

5 Wyatt, A. P., Gut, 1969, 10, 924

Darke, S. G., Parks, A. G., Grogono, J. L., and Pollock, D. J., British Fournal of Surgery, 1973, 60, 169

Brookes, V. S., Waterhouse, J. A. H., and Powell, D. J., British fournal of Surgery, 1968, 55, 405.

${ }^{8}$ Rochlin, D. B., and Longmire, W. P., Surgery, 1961, 50, 586.

Ackerman, L. V., and Del Regato, J. A., Cancer Diagnosis, Treatment and Prognosis, 3rd edn., p. 626. St. Louis, Mosby, 1962.

${ }^{10}$ Haffner, J. F. W., and Semb, L. S., Acta Chirurgica Scandinavica, 1969, $135,543$.

${ }^{11}$ Evans, J. G., and Acheson, E. D., Gut, 1965, 6, 311

12 Goligher, J. C., British Medical fournal, 1941, 2, 393.

13 Smiddy, F. G., and Goligher, J. C., British Medical fournal, 1957, 1, 793.

14 Registrar General, Statistical Review of England and Wales for the Year 1969, Part 1, Tables, Medical. London, H.M.S.O., 1971.

15 Cutler, S. J., and Lourie, W. I., National Cancer Institute Monograph No. 15, p. 281 . U.S. Department of Health, Education, and Welfare, 1964.

\section{Starting Young}

Though the dangers of cigarette smoking ane plain enough to medical men they appear unconvincing to a large number of lay people. But if the young are ever to be deterred from starting the habit at least one necessity is for their elders to set a better example than many do at present. Children would not be human if they did not imitate adults. That plenty do so to become smokers even at the age of 10 is apparent from a recent report. 